\title{
MEMBACA PERSEPSI, MENCERMATI KOMUNIKASI, MEMPREDIKSI HUBUNGAN ANTARUMAT ISLAM DAN HINDU DI KOTA MATARAM, PROVINSI NTB
}

\author{
Kadri $^{1}$ \\ ${ }^{1}$ Universitas Islam Negeri Mataram \\ Email: kadri@uinmataram.ac.id
}

\begin{abstract}
Abstrak
Studi ini fokus untuk mengungkap tiga hal pokok yaitu persepsi, pola komunikasi, dan prospek hubungan antarumat Islam dan Hindu di kota Mataram, provinsi Nusa Tenggara Barat (NTB). Riset kualitatif dengan tradisi fenomenologi ini menjadikan 25 orang umat Islam dan Hindu sebagai informant. Data diperoleh lewat wawancara mendalam, pengamatan, dan dokumentasi, yang selanjutnya dianalisis dengan teknik analisis data fenomenologi dari Van Kaam. Hasil penelitian menunjukkan bahwa umat Islam dan Hindu di kota Mataram saling memberi persepsi positif dan tidak ditemukan stereotype di antara mereka. Persepsi positif dari kedua umat berbeda agama ini simetris dengan keakraban komunikasi yang mereka perlihatkan di ruang publik. Komunikasi yang familiar tersebut tercermin dalam dua pola komunikasi yaitu pola komunikasi aktif yang berlangsung permanen dengan tingkat hubungan emosional yang kuat, dan pola komunikasi pasif yang berlangsung situasional dengan nuansa pragmatisme yang kental. Persepsi positif dan keakraban komunikasi yang ditunjukkan oleh warga Muslim dan Hindu mengindikasikan adanya harmoni di antara mereka sekaligus menjadi indikator tetap terjaganya hubungan baik antara kedua umat mayoritas tersebut di kota Mataram pada masa yang akan datang.
\end{abstract}

Kata Kunci: Persepsi; komunikasi; Muslim; Hindu; komunikasi antaragama

\begin{abstract}
This study aims to unveil three fundamental things, namely perception, communication pattern and the prospect of interreligious relation mainly between Islam and Hindu in the city of Mataram, the capital of NTB (West Nusa Tenggara Province). This qualitative phenomenological study involved 25 participants from both religions. The data, garnered from interview, observation and documentation, were analyzed using Van Kaam's phenomenological data analysis. The empirical evidence showed that the adherents of Islam and Hindu in the capital city of Mataram positively perceived each other without any negative remarks or stereotyping between them. This affirmative perception accorded with their friendly interreligious communication that took place in public sphere. This was depicted by the presence of two patterns of communications, i.e. active communication pattern, a permanent and direct relation associated to strong emotional bound; and passive communication pattern, which was situational with pragmatism nuance. The positive perception and communicative encounters across the two religious adherents indicated the harmonious relation between them, which simultaneously and perpetually consolidated the harmonious relation in the future between the religious believers of the two major religions in the city of Mataram.
\end{abstract}

Keywords: Perception; communication; Muslims; Hindus; Interreligious communication. 


\section{PENDAHULUAN}

Umat Islam dan Hindu adalah dua komunitas mayoritas yang ada di kota Mataram. Data Badan Pusat Statistik (BPS) provinsi Nusa Tenggara Barat (NTB) tahun 2017 menunjukkan jumlah warga Muslim di Mataram tahun 2016 sebanyak 82,00 \% dan warga Hindu sebanyak 14,47 \% (BPS NTB, 2017). Kedua umat beragama tersebut memiliki sejarah panjang dalam menapaki hidup di ibukota provinsi NTB ini, terutama sejak masyarakat Bali berada di kota Mataram sejak tahun 1740 bersamaan dengan ekspansi kerajaan Karangasem di pulau Lombok (Zakaria, 1998: 35). Selama hidup bersama di kota yang bermotto "Maju, Religius, dan Berbudaya" ini kedua umat beragama memperlihatkan dinamika hidup yang dinamis, dengan suasana hidup harmoni mendominasi interaksi di antara mereka, meski terkadang ada konflik di beberapa kampung seperti konflik antara warga Muslim dan Hindu di Kampung Tohpati kecamatan Cakranegara tahun 2013 dan di kampung Pagutan tahun 2017. Fakta ini menunjukkan bahwa konflik antarumat Islam dan Hindu masih menjadi batu sandungan untuk kehidupan harmoni di wilayah pluralis seperti kota Mataram.

Fenomena kekerasan yang berlatarbelakang perbedaan agama (seperti yang terjadi antara umat Islam dan Hindu di kota Mataram) menjadi ironi di saat agama yang sejatinya berperan sebagai pendidik kedamaian bagi pengikutnya. Beberapa ilmuwan memberi perspektif yang berbeda terkait dengan akar persoalan konflik antaragama. Franz M. Suseno (Stokhof \& Djamal, 2003: 12-13) misalnya menggungkapkan setidaknya dua faktor signifikan yang menyebabkan terjadinya fenomena kekerasan (termasuk konflik antaragama) di tanah air yaitu; pertama, modernisasi dan globalisasi telah memasuki masyarakat sehingga melahirkan individualistik dan mengarah ke fundamentalisme agama; kedua, akumulasi kebencian dalam masyarakat. Kecenderungan eksklusifisme semakin meningkat, baik pada komunitas agama maupun pada komunitas etnik. Orang-orang yang berasal dari agama lain dianggap "tidak bertuhan" dan anak-anak disuruh menghindari kontak dengan orang "kafir."

Di samping bersifat makro sebagaimana yang dilihat oleh Suseno di atas, latarbelakang konflik antaragama juga acap kali dilihat dalam perspektif yang lebih mikro, khususnya pada aspek personal atau hubungan antarpersonal atau komunikasi interpersonal. Komunikasi sebagai media interaksi selalu berwajah ganda; di satu sisi dapat menjadi alat membangun harmoni, tetapi pada sisi yang lain sering menjadi penyebab konflik. Konflik yang melibatkan warga Muslim dan Hindu di Mataram pun tidak terlepas dari adanya miskomunikasi di antara mereka. Pada konflik yang terakhir (2017) yang melibatkan dua umat beragama tersebut di kelurahan Pagutan misalnya, lebih disebabkan oleh miskomunikasi dalam pemanfaatan musik sebagai media ritual keagamaan (Miftah et al., 2018: 33). Dalam konteks inilah pentingnya studi relasi umat beragama dengan perspektif komunikasi sehingga terungkap persoalan-persoalan komunikasi antarumat beragama sekaligus direkomendasikan solusi penyelesaiannya.

Meskipun salah satu penyebab konflik antara warga Muslim dan Hindu di kota Mataram adalah faktor miskomunikasi, tetapi hubungan harmonis keduanya (Muslim dan Hindu) di ibukota provinsi NTB ini justru lebih banyak disebabkan oleh faktor komunikasi yang dikelola secara baik oleh mereka. Riset ini menemukan pengalaman komunikasi yang 
baik antara kedua umat berbeda agama tersebut selama mereka hidup bersama di kota Mataram. Pengalaman komunikasi mereka terutama terungkap lewat persepsinya tentang yang lain dan cara mereka berinteraksi di ruang publik. Fenomena persepsi dan komunikasi antarumat beragama menjadi aspek penting dan mendasar untuk melihat gambaran relasi sosial mereka (termasuk prospek hubungan antaragama di masa mendatang) karena persepsi menurut Mulyana (2017: 167) merupakan inti komunikasi.

Riset hubungan antaragama (khususnya antara umat Islam dan Hindu) selama ini didominasi oleh perspektif nonkomunikasi. Riset Mustain dan Umam (2005: 263-264) yang berjudul "Pluralisme Pendidikan Agama dan Hubungan Muslim Hindu di Lombok" misalnya, lebih difokuskan pada perspektif hubungan antargama. Demikian juga dengan riset Jannah (2017: 443-464) yang berjudul "Kegalauan Identitas: Dilema Hubungan Muslimin dan Hindu di Bali" yang lebih banyak melihat dalam konteks hubungan sosial dan psikologis antara kedua umat beragama, atau riset Maknun (2018: 341-366) dengan judul "Harmoni Hindu-Muslim Berbasis Tradisi Lisan Sejarah Desa Saren Budakeling Karangasem Bali” yang telah dimuat dalam Jurnal Fikrah, tahun 2018. Oleh karena itu riset tentang persepsi dan komunikasi antarumat beragama (Islam dan Hindu) akan mengisi kelangkaan perspektif komunikasi dalam memotret hubungan antaragama, terlebih lagi metode yang digunakan adalah pendekatan fenomenologi, yang dapat mengungkap realitas-realitas khas seputar komunikasi antarumat beragama dalam sudut pandang subjek penelitian.

\section{METODOLOGI PENELITIAN}

Riset ini menggunakan tradisi penelitian fenomenologi, yang merupakan salah satu tradisi dalam penelitian kualitatif. Tradisi penelitian ini dianggap tepat untuk mengungkap pandangan atau persepsi masing-masing pemeluk agama (Islam dan Hindu) tentang yang lainnya, termasuk ungkapan pengalaman mereka ketika berinteraksi dengan individu yang beragama lain di ruang publik. Di samping tepat untuk mengungkap realitas subjektif dari masing-masing pemeluk agama, pilihan pendekatan fenomenologi juga menjadi pembeda dengan studi-studi yang lain tentang hubungan antara umat Islam dan Hindu (khususnya di pulau Lombok, seperti studi Suprapto (2017: 77-98) yang menggunakan pendekatan etnografi. Riset tersebut telah dipublikasikan dengan judul "Sasak Muslims and Interreligious Harmony: Ethnographic Study of the Perang Topat Festival in Lombok Indonesia" dalam Journal of Indonesian Islam, edisi Juni 2017. Riset ini juga berbeda dengan riset Wirata (2015: 7-10) yang menggunakan perspektif komunikasi antarbudaya. Hasil riset tersebut telah dipublikasikan dalam Indian Journal of Art, tahun 2015 dengan judul "Inter-cultural Communication between Lokal Hindu and Islamic Community in Perang Topat Ceremony in Lingsar Temple, Narmada District, Lombok".

Riset ini telah dilakukan selama enam bulan (Maret-Agustus 2018) untuk mengumpulkan dokumen terkait, mengamati fenomena, dan mewawancarai 25 orang informan dengan usia, profesi, dan wilayah tempat tinggal yang berbeda di kota Mataram. Untuk menjaga privasi responden, penyebutan nama mereka dalam artikel ini menggunakan inisial. Analisis data dilakukan dengan mengikuti tujuh proses dan teknik analisis fenomenologi dari Van Kaam yaitu yaitu (1) listing and preliminary grouping; (2) reducting and elimination; (3) clustering and thematizing the invariant constituents (thematic 
portrayal); (4) final identification of the invariant constituents and themes by application: validation; (5) individual textural description; (6) individual structural description; and (7) textural-structural description (Pujileksono, 2015: 68-69).

\section{HASIL DAN PEMBAHASAN}

\section{Persepsi Antarumat Muslim dan Hindu di kota Mataram}

Memahami persepsi antarumat beragama (Islam dan Hindu) dinilai penting untuk mendeteksi penilaian atau pandangan mereka terhadap warga beragama lain, dan juga dapat menjadi sinyal utuk menentukan tingkat hubungan di antara mereka. Untuk mendapatkan gambaran tersebut secara komprehensif, pada bagian ini dieksplorasi secara berimbang antara persepsi warga Muslim terhadap warga Hindu, dan sebaliknya juga diungkap persepsi warga Hindu terhadap umat Islam.

Pada umumnya di antara kedua umat berbeda agama tersebut memiliki pandangan yang inklusif dan toleran. Mereka memberi persepsi yang positif terhadap yang lainnya (warga yang berbeda agama dengan mereka). Sebagai contoh, pandangan OKS berikut ini menggambarkan begitu bijaknya beliau memaknai keberadaan warga muslim di kota Mataram.

Bagi kami keberadaan warga muslim di kota Mataram biasa-biasa saja dan sama seperti umat lainnya hidup dalam suasana kebersamaan dalam artian toleransi antarumat beragama cukup tinggi. Hal ini mungkin disebabkan karena penduduk kota Mataram yang heterogen (Wawancara dengan OKS, 2018)

Sebagian warga Hindu lainnya berujar bahwa kedekatannya dengan warga muslim merupakan bagian dari sejarah panjang keberadaan mereka secara bersama di kota Mataram. IWE (wawancara, 2018) misalnya, secara historis IWE menyebut bahwa kebersamaan warga Muslim dan Hindu di kota Mataram telah menjadi bagian dari sejarah. Warga muslim menurutnya sudah sejak dulu berinteraksi dengan warga Mataram yang beragama Hindu. Bahkan lanjutnya, dalam interaksi tersebut sampai pada tataran perkawinan antaragama (Hindu-Muslim Sasak), gotong royong dalam pembangunan tempat ibadah dan pelaksanaan kegiatan keagamaan.

Pernyataan IWE di atas menunjukkan persepsi positifnya terhadap warga Muslim di kota Mataram yang antara lain karena adanya kedekatan emosional di antara mereka yang telah berlangsung lama. Perasaan senada dengan IWE diungkap oleh warga Muslim kota Mataram. MWR misalnya menyebut bahwa sejak dirinya lahir sudah mengenal dan berinteraksi dengan warga Hindu. Kebiasaan inilah menurutnya yang membuat dirinya merasa nyaman bila bersama dengan mereka (warga Hindu) dan kami saling mengundang bila ada hajatan masing-masing (wawancara dengan MWR, 2018).

Testimoni MWR di atas mencerminkan tingkat keberterimaannya terhadap eksistensi warga beragama lain seperti umat Hindu di kota Mataram, termasuk persepsinya yang baik terhadap keberadaan warga Hindu di kota yang dikenal dengan motto "maju, religius, berbudaya" tersebut. Warga muslim lainnya mengakui memiliki teman akrab yang beragama Hindu dan selama lima tahun mereka berteman relatif tidak memiliki persoalan mendasar yang mengharuskan mereka untuk saling membenci atau bermusuhan. Perbedaan agama 
baginya bukan menjadi halangan untuk melanggengkan keakrabanya bersama temannya yang beragama Hindu. Bahkan adanya kasus beberapa oknum yang melibatkan ketegangan antara umat dua agama, tidak sedikitpun menggoyahkan ikatan persahabatan di antara mereka (wawancara dengan JMR, 2018).

Apresiasi warga Hindu terhadap umat muslim di Mataram menjadi catatan penting betapa warga Hindu memiliki persepsi dan juga penilaian baik terhadap perilaku umat muslim. Meskipun diakui bahwa masih ada warga muslim yang tidak berbuat baik terhadap umat Hindu, namun hal tersebut menurut warga Hindu merupakan perilaku oknum, dan mereka (warga Hindu) menyarankan agar persoalan itu bisa diselesaikan secara kekeluargaan atau bisa juga ditangani secara hukum oleh aparat terkait. Hal tersebut secara eksplisit disampikan oleh NSB, salah seorang pengusaha beragama Hindu. Menurutnya, Warga muslim banyak yang baik, meski masih ada segelintir oknum yang melakukan tindak pidana, seperti halnya juga warga Hindu. Kalau ada yang melanggar hukum maka hal tersebut menjadi kewenangan aparat penegak hukum (wawancara dengan NSB, 2018).

Sebagai dua komunitas beragama yang telah memiliki sejarah hidup panjang di kota Mataram, warga Muslim dan Hindu telah merasakan pahit manisnya hidup di antara mereka. Kebersamaan mereka tidak hanya dalam suasana suka, tetapi terkadang dalam suasana "duka" yang sarat ketegangan. Suasana yang disebut terakhir (ketegangan hubungan antara umat Hindu dan warga Muslim) di kota Mataram juga pernah dirasakan oleh para responden. Namun kesalahan yang dilakukan oleh warga berbeda agama dapat dimaklumi dan tidak membuat mereka berprasangka buruk atau berpersepsi negative kepada yang lain. Pernyataan OKS dan IWE (warga Hindu kota Mataram) berikut ini menunjukkan sikap dan persepsi yang baik terhadap warga Muslim.

Kesalahan merupakan hal yang biasa bagi setiap orang karena manusia tidak luput dari kesalahan, bukan saja warga muslim tapi umat lain juga tak luput dari kesalahan yang dilakukan sehari-hari. Kalaupun mereka (warga muslim, pen.) berbuat salah bukan berarti mereka jahat pada kami (wawacara dengan OKS, 2018)

Setiap manusia pastilah pernah melakukan kesalahan, muslim, Hindu, Budha, Katolik pastilah sama. Hanya saja kesalahan yang dilakukan umat Islam terlihat banyak karena memang jumlah umatnya lebih banyak dari umat lainnya. Bila diambil contoh masingmasing umat beragama melakukan kesalahan sepuluh persen, tentulah jumlah pemberitaan umat muslim yang melakukan kesalahan lebih besar. Sementara umat lainnya terkesan melakukan kesalahan sedikit karena jumlah umatnya sedikit, tetapi tetap sama-sama sepuluh persen dari jumlah umatnya melakukan kesalahan (wawancara dengan IWE, 2018)

Tidak sedikitpun rasa dendam dari pernyataan warga Hindu di atas ketika ada kesalahan yang dilakukan oleh warga muslim. Mereka sangat dapat memahami kesalahan tersebut sebagai sifat manusiawi, sehingga tidak ada hubungan yang simetris antara kesalahan yang dilakukan oleh seseorang warga agama tertentu dengan sikap dendam atau kebencian dari warga agama yang lain. Sikap yang diperlihatkan oleh warga Hindu terhadap kesalahan atau kekhilafan warga muslim di atas sama dengan respon/pandangan warga muslim terhadap kelakuan yang sama yang dilakukan oleh warga Hindu di kota Mataram. 
Pernyataan RSM berikut ini menunjukkan sikap akomodatifnya terhadap kekurangan warga Hindu di kota Mataram.

Kesalahan adalah bisa dilakukan oleh siapa saja. Termasuk oleh orang Islam. Kalau kesalahannya terkait dengan saya, tentu saya akan memaafkannya. Tetapi bila kesalahan tersebut terkait dengan masalah hukum berat, tentu harus diselesaikan dengan pendekatan hukum dan akan diproses sesuai dengan hukum yang berlaku (wawancara dengan RSM, 2018)

Warga Muslim dan Hindu di kota Mataram tidak hanya saling memberi respon atas kesalahan yang dilakukan tetapi juga saling memberi apresiasi atas perilaku baik yang mereka lakukan. Di antara perilaku baik tersebut adalah aksi toleransi yang dilakukan oleh mereka terhadap umat berbeda agama. SHD misalnya mengungkap pengalaman bertahuntahun hidup bertetangga dengan warga Hindu.

Saya sejak tahun 1997 tinggal bertetangga dengan orang Hindu. Kami baik-baik saja. Tidak hal yang membuat kami harus bermusuhan. Kalaupun ada persoalan kecil, itu hanya persoalan sepele yang dapat kami selesaikan sendiri, dan setelah itu selesai sudah. Saya senang dengan sikap tetangga saya yang beragama Hindu. Dia sangat mengerti dengan keadaan kami, termasuk sangat mengerti dengan amalan agama Islam yang kami praktekkan sehari-hari (wawancara dengan SHD, 2018).

Sikap yang sama dengan SHD juga diungkap RKE. Meski tidak selama interaksi SHD dengan tetangganya yang beragama Hindu, RKE mengakui bahwa pertemanannya dengan warga muslim tidak menyisahkan persoalan yang serius. Bahkan menurutnya, antara dirinya dengan tetangga saling mendatangi rumah untuk menjalin keakraban sehingga kebersamaan di antara mereka terus terawat dengan baik. RKE sangat menghormati agama tetangganya yang muslim, demikian juga tetangganya sangat memahami dan mengerti seperti apa RKE harus mengamalkan ajaran agama Hindu-nya (wawancara dengan RKE, 2018).

Menurut beberapa responden yang beragama Hindu, warga muslim mudah diajak bergaul dan ramah dalam kehidupan bermasyarakat (wawancara OSW, 2018). Warga muslim menurut NSD memiliki sikap toleran yang tinggi, semangat gotong royong dan persaudaraan yang baik (wawancara dengan NSD, 2018). Hal yang sama diungkap EMI yang menilai bahwa warga muslim sangat ramah dan menerima apa adanya (wawancara dengan EMI, 2018). NSP seorang pengusaha mengakui bahwa warga muslim, terutama yang menjadi karyawannya adalah orang-orang ramah dan jujur sehingga membuat bisnis-nya lebih lancar dan berjalan baik (wawancara dengan NSP, 2018).

Pengakuan yang sama baiknya juga diungkap warga muslim tentang sifat dan karakter warga Hindu. Semua responden beragama Islam mengakui memiliki banyak pengalaman baik saat berinteraksi dengan warga Hindu sehingga mereka memiliki persepsi yang positif terhadap warga Hindu. RKN misalnya, mengungkap pengalaman hidup dan tinggal berdampingan dengan warga Hindu selama puluhan tahun di kota Mataram yang dinilainya memiliki toleransi tinggi terhadap warga muslim (wawancara dengan RKN, 2018). JMR yang baru satu tahun tinggal di kota Mataram merasakan hal yang sama dengan 
RKN. Meski awalnya sebelum pindah ke Mataram JMR memiliki pikiran negatif terhadap orang Hindu. Namun setelah berinteraksi langsung dengan mereka (warga Hindu), asumsi awal dan kekhawatiran selama ini yang terbangun dalam pikirannya menjadi sirna dengan sendirinya karena keramahan dan keakraban yang ditunjukkan oleh teman dan tetangganya yang beragama Hindu (wawancara dengan JMR, 2018).

Seluruh apresiasi antarumat beragama (Muslim dan Hindu) di kota Mataram yang dideskripsikan di atas menunjukkan di antara mereka memiliki persepsi positif. Hal ini menunjukkan bahwa dalam konteks persepsi kedua umat beragama tidak memiliki persoalan sehingga tidak ada kekhawatiran akan munculnya konflik antarwarga Muslim dan Hindu yang berlatarbelakang kebencian atau stereotype di antara mereka. Cara pandang dan persepsi positif seperti ini sejatinya dipertahankan untuk memastikan masa depan hubungan antaragama (khususnya umat Islam dan Hindu) yang baik ke depannya di kota Mataram yang dikenal pluralis.

\section{Pola Komunikasi Warga Muslim dan Hindu di Kota Mataram}

Pola interaksi masyarakat Muslim dan warga Hindu di Kota Mataram mengikuti beragama aktivitas yang mereka lakukan. Dalam setiap bidang aktivitas, mereka memperlihatkan pola interaksi yang berbeda dengan dinamika beragam dan khas. Secara umum riset ini menemukan dua pola komunikasi antara warga Muslim dan Hindu di kota Mataram, yakni pola komunikasi aktif dan pola komunikasi pasif. Dua pola ini ditemukan dalam beragam bidang kehidupan yang dilakoni kedua warga berbeda agama tersebut.

\section{Pola Komunikasi Aktif Warga Muslim dan Hindu}

Komunikasi aktif dalam konteks studi ini dimaknai dengan semua bentuk atau wujud interaksi antarwarga muslim dan Hindu secara aktif dalam setiap kegiatan di masyarakat. Pola komunikasi ini dapat disaksikan dari tingkat partisipasi kedua warga berbeda agama tersebut dalam kesehariannya, terutama pada aktivitas rutin yang mereka lakukan. Pola komunikasi aktif biasanya dilakukan oleh dua atau lebih warga muslim dan Hindu yang memiliki tingkat hubungan baik. Kebaikan hubungan mereka bisa disebabkan oleh banyak hal, seperti kesamaan tempat pendidikan, kolega atau mitra kerja, relasi bisnis, dan beberapa kesamaan lainnya yang lebih pragmatis sehingga memungkinkan mereka untuk selalu bisa ketemu.

Pengalaman RKE (warga Hindu) dengan RDK (warga muslim) antara lain merepresentasikan salah satu pola komunikasi aktif antara warga Hindu dan warga muslim di kota Mataram. Mereka sama-sama kuliah di satu jurusan pada Perguruan Tinggi ternama di kota Mataram. Keakraban mereka tidak hanya di kampus saat hari perkuliahan tetapi juga di luar jam kuliah. Meski mereka tinggal pada tempat berbeda (berjauhan), bukan menjadi penghalang bagi mereka untuk selalu ketemu. Pertemuan mereka pun tidak hanya membicarakan atau mendiskusikan mata kuliah (akademik) tetapi juga terkait dengan persolan non akademik.

Pengalaman yang mirip dengan RKE dan RDK di atas juga dialami RSM dan MDA. RSM adalah seorang muslim taat yang kesehariannya bekerja sebagai guru private dan pengajar bahasa Inggris di beberapa tempat kursus di kota Mataram. RSM juga dikenal 
memiliki relasi luas dan supel dalam pergaulan. MDA adalah mitra kerja RSM di salah satu lembaga kursus di kota Mataram. Relasi kerja inilah yang membuat mereka selalu bertemu paling tidak empat kali seminggu. Namun keakraban mereka tidak sebatas karena hubungan kerja, tetapi di luar jam kerja mereka selalu berkomunikasi dan bertemu, termasuk selalu bertemu dan jalan bareng.

Kedua lelaki lajang tersebut (MDA dan RSM) dalam kesehariannya terlihat akrab. Sepintas tidak terlihat keduanya berbeda agama, kecuali di saat kita dengan serius memperhatikan atribut khas yang melekat dalam tubuh MDA seperti gelang Tridatu yang melilit di tangannya. Keduanya begitu aktif berinteraksi pada tempat dan waktu yang beragam. Oleh karena itu, tidak salah bila mereka dikategorikan sebagai warga muslim dan Hindu yang berkomunikasi aktif.

Pengalaman SHD berbeda lagi. Wanita karier ini tinggal di kompleks perumahan heterogen dalam banyak hal, seperti etnik, agama, usia, profesi, dan berbagai perbedaan lainnya. Kebetulan SHD berada dalam blok yang berdekatan dengan rumah milik warga Hindu. Sebagai tetangga, SHD dan NWH tentu saja terus berinteraksi. Dalam pengamatan peneliti, keduanya termasuk sebagai warga bertetangga yang sangat aktif "bersilaturrahim" dan saling mengunjungi. Setiap ada acara di antara mereka pasti saling membantu, sehingga terlihat layaknya seperti saudara.

Pola komunikasi aktif acap kali terlihat dalam dunia pendidikan, terutama komunikasi yang berlangsung antarsiswa di sekolah-sekolah umum mulai dari tingkat dasar (SD) hingga di level Perguruan Tinggi. Mereka setiap hari bertemu, belajar, dan bermain bersama. Bahkan mereka saling mengunjungi rumah secara bergantian, baik untuk belajar bersama maupun untuk main dan bercengkrama bersama. Ikatan-ikatan emosional di antara pelajar dan mahasiswa Muslim dan Hindu di Kota Mataram terlihat baik. Paling tidak hal ini dibuktikan dengan tidak adanya konflik antarpelajar atau antarmahasiswa berbeda agama (Islam dan Hindu).

Pola komunikasi aktif yang berlangsung di lembaga pendidikan merupakan fenomena yang menggembirakan, apalagi hal tersebut berlangsung pada level pendidikan di tingkat dasar seperti taman kanak-kanak dan Sekolah Dasar. Momentum kebersamaan antaragama lewat komunikasi aktif sejak usia dini menjadi ajang penanaman nilai-nilai inklusivitas pada diri anak. Nilai ini penting di tengah adanya kecenderungan esklusivitas yang dilakukan oleh beberapa lembaga pendidikan dengan cara membatasi diri atau menutup akses bagi orang atau kelompok lainnya.

\section{Pola Komunikasi Pasif Warga Muslim dan Hindu}

Kelompok atau individu yang masuk dalam kategori komunikasi pasif tercatat lebih banyak bila dibandingkan dengan warga Muslim dan Hindu yang melakukan komunikasi aktif di kota Mataram. Interaksi pasif dalam konteks penelitian ini dimaknai sebagai bentuk interaksi yang tidak proaktif antara warga Muslim dan Hindu, atau interaksi antara warga muslim dan Hindu dengan tingkat intensitas yang rendah. Biasanya pola interaksi yang pasif tidak dilandasi oleh adanya ikatan atau hubungan yang kuat secara emosi dari kedua belah pihak. Komunikasi yang berlangsung di antara mereka terlihat "dingin" dan hanya untuk 
memenuhi kepentingan pragmatis sesaat di bidang ekonomi, pendidikan, sosial dan bidangbidang lainnya.

Pengalaman komunikasi JMN (warga muslim) dengan NGR (warga Hindu) menunjukkan begitu pasifnya komunikasi yang mereka lakukan. JMN adalah seorang tukang bangunan, sedangkan NGR adalah pengusaha kayu dan sejenisnya yang membuka bisnis di kota Mataram. Keduanya berinteraksi saat mereka melakukan transaksi jual beli di toko bangunan milik NGR. Jadi komunikasi mereka hanya sebatas sebagai penjual dan pembeli, setelah itu komunikasinya terputus. Saat berkomunikasi, tidak terlihat adanya keakraban di antara mereka.

Di bidang pendidikan juga sering dijumpai praktek komunikasi pasif antara warga Muslim dan Hindu di kota Mataram. Praktek komunikasi pasif di bidang ini dapat ditemukan saat musim pendaftaran siswa baru di tingkat Sekolah Dasar (SD) hingga Sekolah Menengah Atas (SMA). Pertemuan antara orang tua siswa saat mendaftarkan anaknya tidak bisa dihindarkan sehingga komunikasi di antara mereka pun berlangsung. Namun karena pertemuan berlangsung sesaat maka komunikasi yang berlangsung di antara mereka pun tidak terlihat akrab, apalagi komunikasi mereka terputus atau berakhir seiring dengan selesainya urusan masing-masing di sekolah tersebut.

Komunikasi yang lebih pasif dan pragmatis lebih terlihat lagi saat warga Muslim dan Hindu bertemu di pasar tradisional. Transaksi yang berlangsung di pasar berlangsung singkat tanpa ikatan emosional yang kuat. Hampir semua pasar tradisional yang dimiliki kota Mataram berada di dekat perkampungan warga Hindu sehingga setiap harinya pasar dipenuhi oleh warga Hindu dan juga warga Muslim. Namun komunikasi mereka lebih didominasi oleh pola komunikasi yang pasif, dalam artian komunikasi mereka lebih pragmatis dan tidak bersifat kontinyu karena pertemuan atau komunikasi mereka sangat ditentukan oleh kebutuhannya setiap hari yang seringkali berbeda-beda.

Dari dua pola komunikasi (aktif dan pasif) antara warga Muslim dan Hindu di kota Mataram di atas tersirat makna bahwa komunikasi yang berlangsung antara dua komunitas tersebut berlangsung dinamis, yang terkadang intens dan akrab tetapi juga berlangsung spontanitas tanpa hubungan emosional yang mengikatnya. Namun meskipun pola komunikasi di antara mereka masih ada yang berlangsung secara pasif, bukan berarti bahwa hubungan di antara mereka dikategorikan negative apalagi mengarah ke konflik karena komunikasi yang pasif berlangsung situasional dan spontanitas.

\section{Pembahasan}

Persepsi dan pola komunikasi merupakan dua indikator yang digunakan untuk memprediksi hubungan antara warga Muslim dan Hindu di kota Mataram. Hasil penelitian menunjukkan bahwa ada persepsi yang baik di antara dua warga berbeda agama (Islam dan Hindu). Warga Hindu mempersepsikan warga muslim dengan hal-hal yang baik, demikian juga warga muslim memberi persepsi yang positif pada warga Hindu yang ada di kota Mataram. Dengan persepsi positif tersebut dapat dikatakan bahwa tidak ada persoalan emosional yang serius antara warga Hindu dan Muslim di kota Mataram sehingga tidak dikhawatirkan akan munculnya konflik yang dilatarbelakangi oleh persoalan mispersepsi atau yang bersumber dari hal-hal yang bersifat psikis. Dengan demikian dapat dikatakan 
bahwa persepsi positif antara warga Muslim dan Hindu di kota Mataram berkontribusi untuk menghadirkan perilaku baik sehingga harmonis sosial tercipta selama mereka berkomunikasi.

Dalam konteks membangun harmoni maka posisi persepsi sangat strategis. Oleh karena itu, membangun dan merawat persepsi yang baik menjadi salah satu cara untuk menjaga harmoni antarumat beragama (termasuk antara warga Muslim dan Hindu) karena semua perilaku yang mereka lakukan terkait dengan persepsi yang mereka miliki. Semakin positif persepsi seseorang terhadap mitra komunikasinya maka semakin harmonis proses komunikasi yang berlangsung di antara mereka. Demikian juga sebaliknya, suasana komunikasi akan berlangsung tegang dan penuh kecurigaan ketika suasana hati didominasi oleh persepsi negatif terhadap yang lain. Semakin tinggi derajat kesamaan persepsi antarindividu, semakin mudah dan semakin sering mereka berkomunikasi. Rakhmat, 2018: 97) menyebut bahwa perilaku seseorang dalam komunikasi interpersonal amat tergantung pada persepsi interpersonal. Seseorang juga akan berperilaku sesuai dengan apa yang dipersepsikan orang lain terhadap dirinya. Dalam konteks inilah akan terjadi yang namanya self-fulfilling prophecy atau nubuat yang dipenuhi sendiri.

Pandangan di atas mempertegas bahwa eksistensi orang lain dalam berinteraksi menjadi intentitas penting dalam mendukung proses komunikasi. Artinya, masing-masing peserta komunikasi menjadikan persepsi orang lain sebagai referensi dalam mengkonstruksi perilaku komunikasinya, yang oleh Mead (1934) disebut dengan taking the role of the other (pengambilan peran orang lain), atau oleh Cooley (1983) dalam konsep "the looking-glass self' menyebut bahwa konsep diri individu ditentukan oleh apa yang ia pikirkan mengenai pikiran orang lain mengenai dirinya (Mulyana, 2018: 111). Berdasarkan asumsi teoritik tersebut maka dapat dikatakan bahwa harmoni sosial antara warga Muslim dan Hindu di kota Mataram tidak cukup bila keduanya memproduksi persepsi positif tetapi harus dilengkapi dengan upaya pemaknaan terhadap persepsi tersebut. Bila masing-masing mereka memaknai persepsi positif dari yang lain maka mereka akan mengkonstruksi perilaku-perilaku positif selama mereka berkomunikasi.

Persepsi positif dan komunikasi yang baik dalam interaksi antarumat Islam dan Hindu di kota Mataram merupakan cermin kesediaanya menghormati perbedaan. AlMunawar (2005: 13) menyebut bahwa prinsip toleransi antaragama antara lain ditunjukkan dengan menghormati perbedaan atau keyakinan orang lain tanpa mengorbankan keyakinan sendiri. Kebersamaan mereka pada urusan duniawi adalah bagian dari cara merawat harmoni, terutama pada aspek-aspek yang teknis (bukan dalam persoalan yang prinsipil seperti ideologi atau keyakinan). Riset ini menemukan adanya sikap dan perilaku saling menghormati perbedaan antara warga Muslim dan Hindu di kota Mataram. Dalam konteks komunikasi antarbudaya, perilaku saling menghargai perbedaan agama sebagaimana yang ditunjukkan oleh warga Muslim dan Hindu di Kota Mataram merupakan kunci suksesnya komunikasi antarbudaya. Bahkan perbedaan kewarganegaraan di level rumah tangga pun, prinsip saling menghargai tetap menjadi kunci sukses komunikasi antarbudaya (Rosalyn \& Kuncoroyakti, 2019: 37), apalagi perbedaan agama yang melibatkan dua orang yang tidak memiliki ikatan pernikahan seperti dalam riset ini (warga Muslim dan Hindu di Kota Mataram). 
Dengan persepsi positif yang dimiliki oleh warga Muslim dan Hindu maka dapat diprediksi prospek hubungan di antara mereka ke depan akan berlangsung harmonis. Faktor persepsi tidak hanya dijadikan sebagai salah satu indikator untuk menilai indeks toleransi (Hermawati et al., 2017: 105-124) tetapi juga menjadi unsur penting dalam membangun harmoni sosial (termasuk harmoni antaragama). Ahmad (2013: 61-62) menyebut bahwa konflik-konflik yang muncul antara pemeluk suatu agama dengan pemeluk agama lainnya bisa berasal dari adanya persepsi yang keliru atau pandangan jelek terhadap agama lain dan pemeluknya. Persepsi ini muncul setelah mereka melihat dan memberikan penilaian terhadap kelompok agama lain tersebut yang dianggapnya merugikan agama atau kelompok mereka. Dalam konteks inilah pentingnya merawat persepsi positif dan menjaga relasi sosial yang baik antara umat berbeda agama seperti warga Muslim dan Hindu di kota Mataram.

Persepsi positif dari masing umat beragama (Islam dan Hindu) di kota Mataram memiliki korelasi dengan baiknya komunikasi yang terjalin di antara mereka, terutama saat mereka melakukan komunikasi aktif di ruang publik. Kebersamaan antara umat Islam dan Hindu dalam satu tempat usaha atau tempat lainnya yang ditemukan dalam riset ini merupakan bentuk pemanfaatan ruang bersama di antara mereka. Pemanfaatan ruang bersama seperti ini penting untuk merawat harmoni karena mereka bisa berinteraksi dan mengkomunikasikan banyak hal di ruang bersama tersebut. Asumsi ini sejalan dengan temuan Suprapto (2013: 334) dalam risetnya tentang hubungan antara Muslim dan Hindu di kota Mataram yang secara eksplisit menemukan bahwa ketegangan antaragama antara lain disebabkan oleh makin berkurangnya ruang publik (public spaces) seperti ruang terbuka hijau, sarana olahraga dan kesenian yang menjadi tempat semua komunitas berinteraksi dan mempererat ikatan sosial tanpa dihalangi oleh unsur primordial seperti agama dan suku.

Dalam hubungannya dengan persepsi, keberadaan ruang public seperti toko dan pasar sebagai tempat berkomunikasinya warga Muslim dan Hindu di Kota Mataram juga dapat dimaknai sebagai factor situasional (Bahfiarti, 2016: 37) atau factor eksternal (Thoha, 2007: 154) yang mempengaruhi persepsi. Salah satu jenis factor eksternal yang mempengaruhi persepsi menurut riset Syaras dkk (2019: 16) adalah faktor intensitas komunikasi dan penerimaan pesan. Asumsi ini dimungkinkan terjadi saat warga Muslim dan Hindu di Kota Mataram berkomunikasi saat sama-sama berbisnis dengan intensitas komunikasi yang berlangsung setiap hari. Akumulasi kebaikan yang terus dirasakan oleh orang-orang berbeda agama setiap hari saat berkomunikasi akan memperkokoh persepsi baik mereka terhadap individu yang beragama lain.

Interaksi dan komunikasi antarumat beragama di ruang publik yang dilakukan oleh warga Muslim dan Hindu di kota Mataram mengindikasikan adanya kemauan mereka untuk menghilangkan sekat-sekat primordialisme. Umat beragama yang tidak terlibat dalam interaksi sosial dengan umat beragama lain sama dengan umat beragama yang membangun sekat sosial dan membiarkan dirinya terkungkung dengan komunitasnya serta cenderung memproduksi kecurigaan kepada umat beragama lain. Oleh karena itu tidak salah bila Saefuddin (2015: 11) menyebut bahwa salah satu faktor penyebab konflik antaragama adalah karena adanya sikap tertutup dan saling curiga antar agama. Sikap tertutup dari masingmasing umat beragama akan berkontribusi bagi ketegangan hubungan di antara mereka. Oleh 
karena itu, Muhtadi (2019: 5) menyebut bahwa ketegangan antarumat beragama akan semakin sulit diurai ketika kebekuan komunikasi terus melilit umat beragama.

Komunikasi dan hubungan harmonis antaragama dapat dijamin bila masing-masing umat beragama bisa bersikap terbuka dan mengkomunikasikan apapun secara baik dengan mitra komunikasinya sembari terus menunjukkan kesamaan di antara mereka. Dengan cara inilah maka irisan perbedaan antarumat beragama bisa diminimalisir, sebab bila unsur-unsur yang berbeda terus diperbesar dan ditonjolkan maka akan tumbuh subur prasangka di antara warga berbeda agama. Prasangka dalam konteks komunikasi menurut Effendy (2007: 49) merupakan salah satu rintangan atau hambatan berat bagi suatu kegiatan komunikasi. Liliweri (2003: 338) menilai bahwa ketidakefektifan hubungan (komunikasi) antaretnik (termasuk antaragama) antara lain disebabkan oleh adanya stereotip (prasangka). Prasangka atau stereotip merupakan penghambat komunikasi antarbudaya, dan bahkan stereotype disebut oleh Purwasito, 2015: 322) sebagai penghambat potensial dalam komunikasi antarbudaya. Antara masyarakat yang berbeda budaya cenderung ber-stereotip terhadap masyarakat yang berbudaya lain. Stereotip bisa diminimalisir atau bahkan dihilangkan bila ada komunikasi yang rutin dan interaksi yang intensif antara orang berbeda budaya. Dengan komunikasi yang inten (apalagi berlangsung dalam suasana yang inklusif), maka kecurigaan dan prasangka akan semakin terkikis, dan digantikan oleh rasa saling percaya di antara warga berbeda agama (seperti muslim dan Hindu di kota Mataram).

Warga Muslim dan Hindu di kota Mataram termasuk dua warga berbeda agama yang memiliki komunikasi yang intens, bahkan ada yang sampai pada tingkat kerjasama. Komunikasi di level inilah yang dalam riset ini dikategorikan sebagai pola komunikasi aktif. Dalam perspektif komunikasi antaragama, bentuk komunikasi yang melibatkan umat berbeda agama dalam wujud kerjasama di dunia sosial dapat dimaknai sebagai bentuk "dialog antariman". Tujuan dialog antariman menurut Abu Nemer (Khamami, 2014: 249271) sesungguhnya adalah untuk membantu komunitas yang terpecah dan terkotak-kotak agar saling memahami dan saling menghormati. Seseorang yang tidak memiliki pengalaman dialog sama sekali akan gamang dalam membangun cara pandang hidup bersama. Dialog antariman tidak hanya terkait dengan konten-konten yang serius seperti konsep ajaran tetapi juga mengenai tema-tema ringan seputar dunia keseharian. Fenomena dialog yang ditemukan dalam riset ini lebih pada konten-konten keseharian yang menjadi rutinitas masyarakat berbeda agama di kota Mataram. Dalam konteks inilah pentingnya memperbanyak ruang sosial pragmatis yang bisa mempertemukan kedua umat beragama agar dialog antarumat beragama terus berlangsung.

Persepsi positif dan komunikasi aktif antarumat Islam dan Hindu di kota Mataram tidak hanya atas pertimbangan pragmatis tetapi juga karena faktor ikatan emosional terkait dengan sejarah keberadaan mereka di kota Mataram. Kedua umat beragama sadar kalau nenek moyangnya sudah hidup bersama sejak tahun 1740 (Sastrodiwiryo, 1996), bersamaan dengan ekspansi kerajaan Karangasem Bali di pulau Lombok. Kesadaran warga Hindu dan Muslim akan kebersamaan panjang mereka di kota Mataram khususnya dan pulau Lombok pada umumnya telah menunjukkan adanya hubungan emosional di antara mereka. Dalam konteks komunikasi, kesadaran ini akan membantu terciptanya komunikasi efektif antarumat beragama (khususnya umat Islam dan Hindu) di kota Mataram karena menurut Mulyana 
(2017: 107), komunikasi akan efektif bila ada kesamaan latarbelakang sosial budaya di antara orang-orang yang terlibat dalam komunikasi.

Riset ini telah menemukan pentingnya persepsi positif dan komunikasi harmoni atau kerjasama antarumat beragama, sehingga diprediksi menjadi modal sosial (social capital) bagi masa depan hubungan antaragama yang harmonis. Modal-modal sosial seperti ini butuh perawatan dengan berbagai cara, seperti penanaman nilai-nilai inklusivitas di semua level dan bidang kehidupan atau dengan cara memperbanyak ruang perjumpaan antarumat beragama baik lewat sarana public atau momentum kerjasama di semua bidang kehidupan. Strategi ini tidak cukup mengharapkan kesadaran personal atau kelompok tetapi juga membuthkan support kebijakan dan program dari pemerintah sehingga upaya memmbangun harmoni sosial antaragama di wilayah pluralis (seperti kota Mataram) akan lebih paripurna dan membuahkan hasil maksimal.

\section{PENUTUP}

Persepsi antarumat Islam dan Hindu di kota Mataram teridentifikasi berdimensi positif tanpa ada prasangka dan stereotipe di antara mereka. Kedua umat beragama bisa saling menyadari perbedaan yang dimiliki dan memahami kesamaan serta hubungan emosional di antara mereka. Tidak ditemukannya persepsi negatif dari masing-masing umat beragama menjadi sinyal positif akan adanya hubungan harmonis antara umat Islam dan Hindu di kota Mataram di masa yang akan datang.

Persepsi positif dari masing-masing umat beragama berkorelasi dengan hubungan baik yang mereka tunjukkan, terutama lewat komunikasi mereka di ruang publik. Ditemukan setidaknya dua pola komunikasi antara umat Islam dan Hindu di kota Mataram yaitu pola komunikasi aktif dan pola komunikasi pasif. Pola komunikasi aktif dilakukan dengan penuh keakraban dan hubungan emosional yang kental, bahkan hingga sampai tahap kerjasama permanen. Sementara pola komunikasi pasif dilakukan secara situasional atas dasar kepentingan pragmatis. Pola komunikasi aktif sejatinya harus terus dirawat dan ditingkatkan untuk menjamin terciptanya harmoni antarumat Islam dan Hindu di kota Mataram.

Persepsi dan komunikasi merupakan dua hal yang terkait karena baik atau tidaknya hubungan komunikasi antarumat beragama antara lain ditentukan oleh positif atau negatifnya persepsi yang mereka bangun terhadap umat beragama lain. Positifnya persepsi antarumat beragama dan baiknya komunikasi yang terjalin di antara mereka merupakan dua indikator yang dapat dijadikan sebagai referensi untuk memprediksi keharmonisan hubungan antara umat Islam dan Hindu di wilayah pluralis seperti kota Mataram, terlebih lagi pola komunikasi aktif tersebut lebih banyak dilakukan oleh warga yang berstatus pelajar.

\section{REFERENSI}

Ahmad, H. A. (2013). Survei Nasional Kerukunan Umat Beragama di Indonesia. Puslitbang Kehidupan Keagamaan Badan Litbang dan Diklat Kementerian Agama RI.

Al-Munawar, S. A. H. (2005). Fikih Hubungan Antar Agama. Ciputat Press. 
Bahfiarti, T. (2016). Komunikasi Keluarga (Suatu Pendekatan Keberlanjutan Regenerasi Anak Petani Kakao di Provinsi Sulawesi Selatan). Kedai Buku Jenny.

BPS NTB. (2017). NTB dalam Angka. BPS NTB.

Cooley, C. H. (1983). Uman Nature and the Social Order. Schoken Books.

Effendy, O. U. (2007). Ilmu, Teori, dan Filsafat Komunikasi. PT. Cipta Aditya Bakti.

Hermawati, R., Paskarina, C., \& Runiawati, N. (2017). Toleransi Antar Umat Beragama di Kota Bandung. Umbara, 1(2). https://doi.org/10.24198/umbara.v1i2.10341

Jannah, S. R. (2017). Kegalauan Identitas: Dilema Hubungan Muslimin dan Hindu di Bali. Ulumuna, 16(2), 443-464. https://doi.org/10.20414/ujis.v16i2.186

Khamami, A. R. (2014). DIALOG ANTAR-IMAN SEBAGAI RESOLUSI KONFLIK TAWARAN MOHAMMED ABU-NIMER. Al-Tahrir: Jurnal Pemikiran Islam, 14(2), 249. https://doi.org/10.21154/al-tahrir.v14i2.123

Liliweri, A. (2003). Dasar-Dasar Komunikasi Antarbudaya. Pustaka Pelajar.

Maknun, M. L. (2018). Harmoni Hindu-Muslim Berbasis Tradisi Lisan Sejarah Desa Saren $\begin{array}{llll}\text { Budakeling Karangasem } \quad \text { Bali. } & \text { FIKRAH, }\end{array}$ https://doi.org/10.21043/fikrah.v6i2.4005

Mead, G. H. (1934). Mind, Self, and Society: From a Standpoint of a Social Behaviorist. Editor Charles W. Morris. The University of Chicago Press.

Miftah, Mawardi, Kadri, \& Suprapto. (2018). Konflik, Kekerasan, dan Ekstremisme: Melacak Akar Penyebab, Potensi \& Resolusinya di Nusa Tenggara Barat. PPIM - NC.

Muhtadi, A. S. (2019). Komunikasi Lintas Agama. Simbiosa Rekatama Media.

Mulyana, D. (2017). Ilmu komunikasi: Suatu pengantar. Remaja Rosdakarya.

Mulyana, D. (2018). Metodologi Penelitian Kualitatif: Paradigma Baru Ilmu Komunikasi dan Ilmu Sosial Lainnya. PT. Remaja Rosdakarya.

Mustain, \& Umam, F. (2005). Pluralisme Pendidikan Agama dan Hubungan Muslim Hindu di Lombok. LKIM IAIN Mataram.

Pujileksono, S. (2015). Metode Penelitian Komunikasi. Intrans Publishing.

Purwasito, A. (2015). Komunikasi multikultural (Cetakan I). Pustaka Pelajar.

Rakhmat, J. (2018). Psikologi Komunikasi. PT. Remaja Rosdakarya.

Rosalyn, M. E., \& Kuncoroyakti, Y. A. (2019). KOMUNIKASI ANTAR BUDAYA PADA KOMUNITAS PERCA (STUDI FENOMENOLOGI). Jurnal Riset Komunikasi, 2(1), 29-37. https://doi.org/10.24329/jurkom.v2i1.51

Saefuddin, T. (2015). Memahami Konflik Antar Iman: Menyikapi Perbedaan Sebagai "Rahmat" dan Bukan "Konflik. Jurnal Al-Adyaan, 1(2).

Sastrodiwiryo. (1996). Perjalanan Dang Hyang Niratha Sebuah Daharmayatra 1478-1560 dari Daha sampai Tambora. Bali Post.

Stokhof, W. A. L., \& Djamal, M. (2003). Konflik Komunal di Indonesia Saat Ini. Kerja sama INIS Universiteit Leiden dan Pusat Bahasa dan Budaya Universitas Islam Negeri Syarif Hidayatullah.

Suprapto. (2013). Semerbak dupa di pulau seribu masjid: Kontestasi, integrasi, dan resolusi konflik Hindu-Muslim (Cetakan ke-1). Kencana. 
Suprapto, S. (2017). SASAK MUSLIMS AND INTERRELIGIOUS HARMONY: Ethnographic Study of the Perang Topat Festival in Lombok - Indonesia. JOURNAL OF INDONESIAN ISLAM, 11(1), 77. https://doi.org/10.15642/JIIS.2017.11.1.77-98

Syaras, D., Yasir, Y., \& Wirman, W. (2019). KOMUNIKASI INTRAPERSONAL PASIEN HYPNOBIRTHING DI RUMAH SAKIT BERSALIN ANNISA PEKANBARU. Jurnal Riset Komunikasi, 2(1), 13-20. https://doi.org/10.24329/jurkom.v2i1.49

Thoha, M. (2007). Perilaku Organisasi Konsep Dasar dan Aplikasinya. RajaGrafindo Persada.

Wirata, I. W. (2015). Wirata, I.W. (2015). "Inter-cultural Communication between Lokal Hindu and Islamic Community in Perang Topat Ceremony in Lingsar Temple, Narmada District, Lombok", Indian Journal of Art, vol 5 No. 13, 7-10. Indian Journal of Art, 5(13), 7-10.

Zakaria, F. (1998). Mozaik Budaya Orang Mataram. Yayasan Sumurmas Al-Hamidy. 